\title{
Using Geoelectrical Imaging to Recognize Zn-Pb Post-Mining Waste Deposits
}

\author{
Jolanta Pierwola* \\ Faculty of Earth Sciences, University of Silesia, \\ Bedzinska 60, 41-200 Sosnowiec, Poland
}

Received: April 8, 2015

Accepted: June 4, 2015

\begin{abstract}
This paper presents the results of resistivity-IP imaging for two sites where $\mathrm{Zn}-\mathrm{Pb}$ post-mining wastes are deposited. At the first one the historical washed waste and tailings were stored directly on the soil. In the second location tailings were used as filling material for the reclaimed sinkhole. For both of the investigated locations differences between the geoelectrical properties of the waste and surrounding sediments were noticed. The tailings are characterized by lower resistivity and increased normalized chargeability in comparison to the natural sediments. These features are caused by the presence of the $\mathrm{Fe}$ and $\mathrm{Pb}$ sulphides and clay minerals. Washed waste exhibited raised resistivity, but it was lower than values observed for uncontaminated sediments. This kind of waste does not show increased chargeability.
\end{abstract}

Keywords: $\mathrm{Zn}-\mathrm{Pb}$ tailings, Olkusz, ERT, TDIP imaging, acid drainage

\section{Introduction}

Exploitation of $\mathrm{Zn}-\mathrm{Pb}$ ores in the Olkusz region (southern Poland) has been conducted since the Middle Ages. During the $19^{\text {th }}$ and $20^{\text {th }}$ centuries the output significantly increased. The long-lasting mining activity results in significant changes of the surface morphology and also of the underground water regime. Mining works - especially historic ones - were executed using the underground method, which caused a large number of synclines, sinkholes, and other post-mining structures. On the other hand, numerous places were chosen to store the gangue and waste-material derived from the ore enrichment processes. The locations of the contemporary storage yards are well-known, but the position of a large number of abandoned storage areas is completely unknown. This information is important, because even after a long storage period the waste material is still chemically very active [1] and it is a serious threat for the environment.

*e-mail: jolanta.pierwola@us.edu.pl
Huge amounts of waste material are produced as a byproduct of the ore flotation processes and stored in tailing ponds. Nowadays some attempts at using tailings for the reclamation of post-mining structures have been undertaken.

A quantity of geochemical and mineralogical studies on the environmental influence of the waste material coming from mining and processing of the polymetallic ores has been reported in literature during the last decade. The studies on behavior of tailings and others metal-containing waste were conducted in the USA [2, 3], Macedonia [4], Belgium [5], Peru [6], Spain [7], and Tunisia [8, 9]. The main reason for the presented research undertaking was a considerable threat to the surface and underground waters resulting from the chemical composition of the stored material, which contains a quantity of toxic metallic elements such as zinc, lead, arsenic, manganese, cadmium, or thallium [1, 10-12]. In the waste the above-mentioned metals are chemically bound in the sulphur compounds, mainly sulphides and sulphates. An oxidation of sulphides due to groundwater drainage causes the mobilization of 
harmful acid. The occurrence of metalliferous sulphates and gypsum stored for many years in mine waste triggers low $\mathrm{pH}$ value and intensifies geochemical interactions. In an environment where the low value of $\mathrm{pH}$ occurs, the metal compounds are unstable and the toxic metals are leaching from tailings into the soil and water. Thus the location of the sites where waste was stored and the estimation of the influence of the stored waste becomes a crucial issue.

Two sites where the $\mathrm{Zn}-\mathrm{Pb}$ post-mining wastes are stored were chosen for the geoelectrical survey (Fig. 1) presented in this paper. The first is the abandoned "Józef" waste-dump in a suburb of Olkusz, Poland. The age of the waste is estimated at 80 years. This site was an area of geochemical and geophysical studies presented by J. Cabała and others [1]. The second one, situated near Bukowno, is a post-mining sinkhole reclaimed with the use of tailings from the nearby tailing pond.

\section{Geological and Hydrogeological Structure of the Investigated Area}

The area of investigation includes $\mathrm{Zn}-\mathrm{Pb}$ mineralization near the roof of the thick carbonate complex that belongs to the Lower and Middle Triassic. The gangue top layer with a thickness $10-40 \mathrm{~m}$, called the diplopora dolomite, is characterized by the existence of cracks and cavities, commonly filled with a limonitic material. Sedimentary cover is not continuous, and the Upper Triassic clays, mudstones, and marls are found only locally. Over the Triassic rocks there are Pleistocene-age diluvial sands and clays with the pieces of the older rocks and the post-glacial sands, clays, and gravels.

In the area of survey two hydraulically connected water-bearing levels were ascertained. The first of them, supplied by rainfalls, is located in fine and middle-grained Quaternary sands. The main, karst-fissure aquifer exists in the Triassic limestones and dolomite, which are characterized by the large porosity and the dense system of cracks and caves. Both aquifers are strongly influenced by human activity and intensively drained by mining works, thus the water level is situated at a depth of about $70 \mathrm{~m} \mathrm{[13].}$

\section{Geoelectrical Survey}

Studies of the tailings from the Olkusz region suggest noticeable differences in physical properties of the tailings and natural soils. The waste material is characterized by higher electrical conductivity, specific gravity, bulk density, and lower porosity [1, 14] than surrounding sediments. If there are differences in physical properties the field geophysical methods capacitate fast and efficient identification of the contaminated areas.

Among a number of geophysical techniques the geoelectrical methods seem to be the most promising in investigations of the waste and detection of acid mine drainage (AMD). Martinez-Pagan et al. [15] and Gomez-Ortiz et al. [16] successfully employed the electrical resistivity tomography (ERT), and Iacob [17] used vertical electrical sounding (VES) methods to determine geometry and thickness of the tailing ponds in Spain and Romania. Iacob [18] applied the VES method to identify the oxidation and reduction zones within the tailings. To obtain more reliable results the geoelectrical methods are completed with other surface geophysical methods. Iacob and Orza [19] applied the resistivity, conductivity, and magnetic measurements to investigate two waste-dumps in central-western Romania. To characterize the internal structure of the tailings over an abandoned tailing lagoon in a Central Welsh ore field.

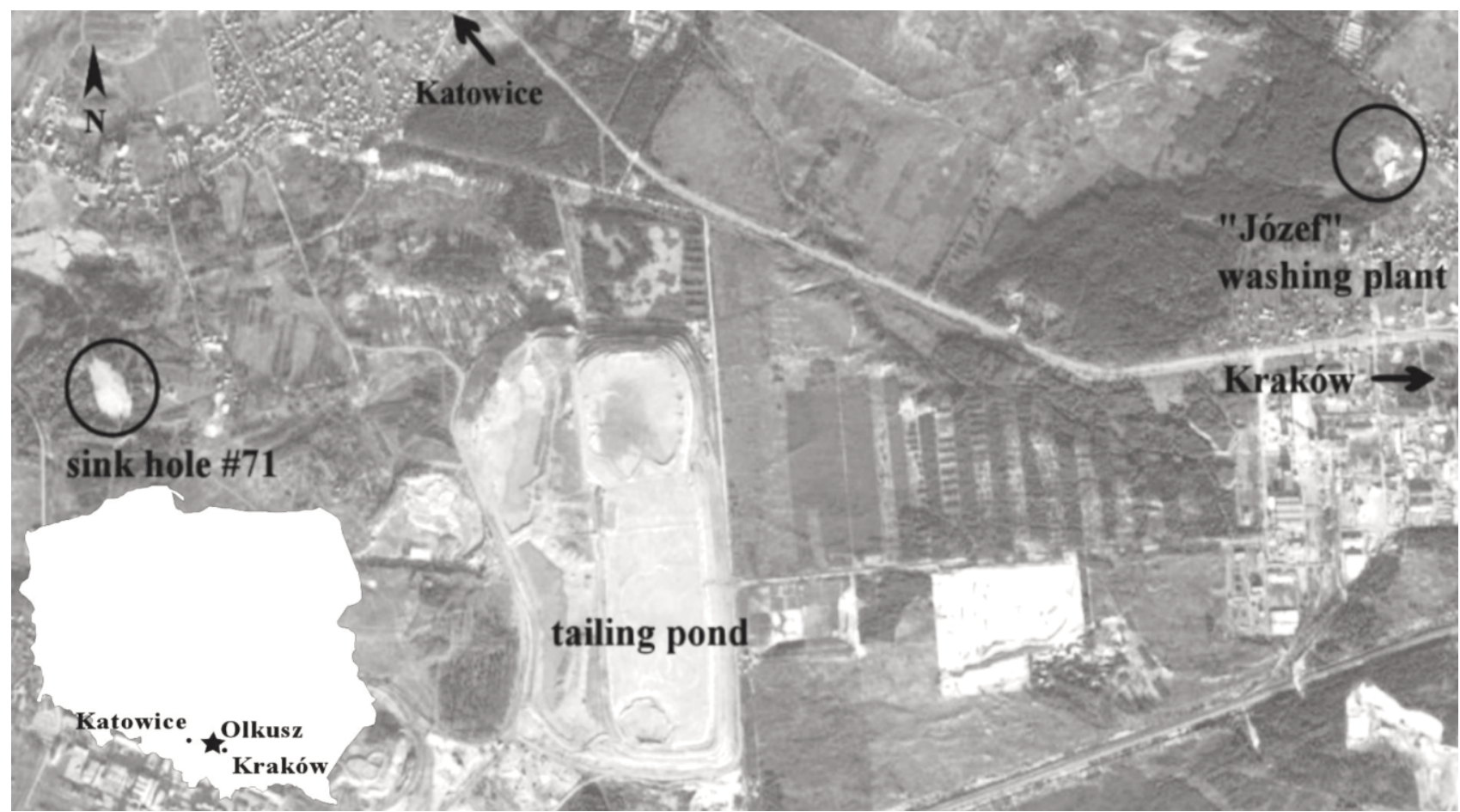

Fig. 1. Location of geoelectrical measurements (accor. Google Earth). 
Kuras et al. [20] used a combination of ERT and groundpenetrating radar (GPR) surveys. For the same purpose Lghoul et al. applied a combination of ERT and seismic refraction tomography in Morocco [21], and HuotariHalkosaari and Lerssi [22] a combination of ERT and transient electromagnetic methods (TEM) in Finland. The electromagnetic methods capacitate fast geophysical reconnaissance of the polluted area [23]. Cabala et al. [1] obtained promising results in distinguishing clear sands and two kinds of waste based on the results of EM measurements in the Olkusz region.

For both locations selected for this paper electrical imaging (ERT) and time domain induced polarization (TDIP) imaging were applied. During the last decade the IP method has become a useful tool that helps to distinguish between sediments of different lithological compositions $[24,25]$ and hydraulic characteristics $[25,26]$. The use of the induced polarization method for the investigated waste was reasonable, because the waste contains high amounts of sulphides such as galena, pyrite, and marcasite, and clay minerals (kaolinite, illite). The presence of these polarizable minerals would help to distinguish the waste material from the surrounding sediments.

Some attempts on avail the IP measurements for the tailings were conducted by Yuval and Oldenburg [27]. They tried to correlate the chargeability with the sulphide concentration. Campbell and Fitterman [28] emphasized the potential possibility of discriminating between metalliferous sulphides and sulphates based on results of resistivity and IP measurements. De Villiers et al. [29] used the abovementioned method in conjunction with ERT to map the extent of the acidic water. Placencia-Gomez et al. [30] suggested the sensitivity of the spectral induced polarization method (SIP) method to discriminate AMD discharges from reactive oxidation zones in tailings.

\section{Józef Waste Dump}

One of the numerous sites in which the ore was processed and the waste was stored is in Olkusz Stary, the western district of Olkusz. The Józef washing plant operated into the turn of the $20^{\text {th }}$ century. The waste from the enrichment processes was piled up on an area of about
6 ha in a shape of irregular dumps and piles, directly on the surface. The area of storage was isolated neither vertically nor horizontally. When the washing plant finished its activity the total volume of waste stored was estimated at 177,000 tons. Deposited waste contained about $7.8 \%$ of $\mathrm{Zn}$ and $1.4 \%$ of $\mathrm{Pb}$. In the 1960 s and 1970 s a quantity of waste was utilized as the raw material in the smelting works in nearby Bukowno. In 2008 more than 10,000 tons remained on the stockyard. During 2008-09 some attempts of reclamation of the former stockyard were made.

The shape of the surface before the waste dump was formed is not known. The geological structure can be approximated on the basis of the geological map and two archival boreholes that were found in the vicinity of the storage yard (Fig. 2). Both of them were situated approximately $200 \mathrm{~m}$ from the dump: one to the NE, the other to the SW. According to the information obtained from drilling, the roof of the carbonate complex (the diplopora dolomite) is found 6-9 $\mathrm{m}$ below ground level, but locally its depth can significantly change, because of the subsidence resulting from the ore extraction process. The dolomite layer is weak and considerably fractured - numerous fissures with a width of about $2 \mathrm{~cm}$ have been noticed. Over the dolomite toward east and northeast of the dump there are the Upper Triassic (Keuper), strongly weathered clays with a thickness of about $8 \mathrm{~m}$. Above the clay a thin layer $(0.5 \mathrm{~m})$ of sandy soil was identified. To the south the clay layer is thinning out. In the borehole southeast of the waste-dump area dolomite was drilled directly below the six-metre-thick dolomitical diluvium. To the north and northwest of the dump Quaternary fluvioglacial sands were noticed on the surface.

The stored waste material comes from two technological processes applied to different types of ores, thus its chemical composition is not uniform. The washed waste is characterized by a rust-color and domination of mediumand coarse-grained sandy fraction. For this type of waste the dominant minerals are dolomite, calcite, and clay. It also contains gypsum, the Fe oxides and hydroxide, and relicts of sphalerite and galena. The filtration coefficient in a range of $1.77 \cdot 10^{-6} \div 9.04 \cdot 10^{-4} \mathrm{~m} / \mathrm{s}[10]$ indicates that this material is very permeable for water infiltration.

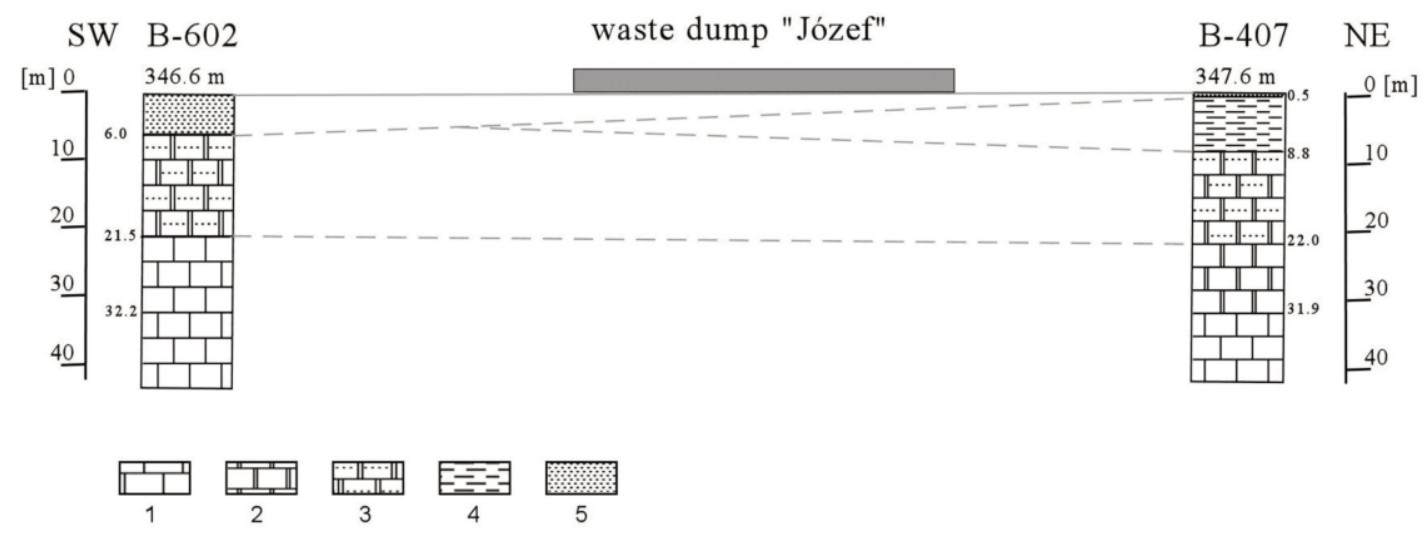

Fig. 2. The lithological profiles in the vicinity of the Józef washing plant:

1 - limestone $\left(T_{2}\right), 2$ - dolomite $\left(T_{2}\right), 3$ - diplopora dolomite $\left(T_{2}\right), 4$ - clay (Keuper, $\left.T_{3}\right)$, and 5 - dolomitical diluvium (Pleistocene). 
The second type of waste, of a grey colour, includes tailings. For this waste the content of sandy, clayey, and dusty fraction is in almost equal proportions. The tailings are characterized by the high content of $\mathrm{Pb}$ and $\mathrm{Zn}$ minerals (mainly sulphides) and gypsum (10\%), and Fe sulphides such as pyrite and marcasite. The filtration coefficient is considerably lower than for the red waste [10].

The meteoric water in the area of tailings is drained as surface flow, resulting in filling of the local depressions with a clayey fraction of waste.

The common feature of the rusty and grey waste is very high $\mathrm{Pb}$ content. Furthermore, the rusty waste includes high concentrations of $\mathrm{Cd}$ and $\mathrm{Tl}$. Their contents exceed several orders of magnitude standards which are acceptable for industrial soils (Table 1). Less toxic elements, such as Zn, $\mathrm{Fe}$, and $\mathrm{Mn}$, are also meaningful components of minerals observed in the analyzed waste dump.

As previously mentioned, heavy metals compounds become unstable at low $\mathrm{pH}$ conditions and they can be easily leached from the waste. The $\mathrm{pH}$ value was estimated at 2.5-3.9 for grey and 5.5-5.7 for red waste [1]. That is why the mobility of metals in the waste should be considered as significant, and its influence on soil and water quality should be carefully studied. In both waste types a certain amount of jarosite, which is an indicator of an active acid drainage process, was found. Thus, the waste stored should be treated as a meaningful source of water and soil pollution in spite of tens of years of standing storage.

The results of initial geophysical measurements carried in this area with an EM31-MK2 Geonics conductivity meter [1] were very promising and suggested the existence of the noticeable differences in the waste material (very high apparent electrical conductivity) in comparison to the surrounding soils. The above-mentioned differentiation seems to be a useful feature that might be availed for the identification of areas in the Olkusz region where the postmining waste is stored. Some doubts come from the fact that the apparent conductivity obtained by the authors for the vertical dipole (depth $6 \mathrm{~m}$ ) was higher than that for the horizontal dipole orientation (depth $3 \mathrm{~m}$ ). This observation suggests that the source of the change observed can be found in the basement of the waste dump. To check whether the differentiation ascertained by the EM reconnaissance was not connected with the changes of the deeper geology and to define the vertical range of the accumulated waste, the resistivity and induced polarization imaging measurements using a LUND Imaging System (ABEM) were realized.

Two survey lines crossed the area of the earlier EM reconnaissance (Fig. 3). The first of these lines (profile 1)

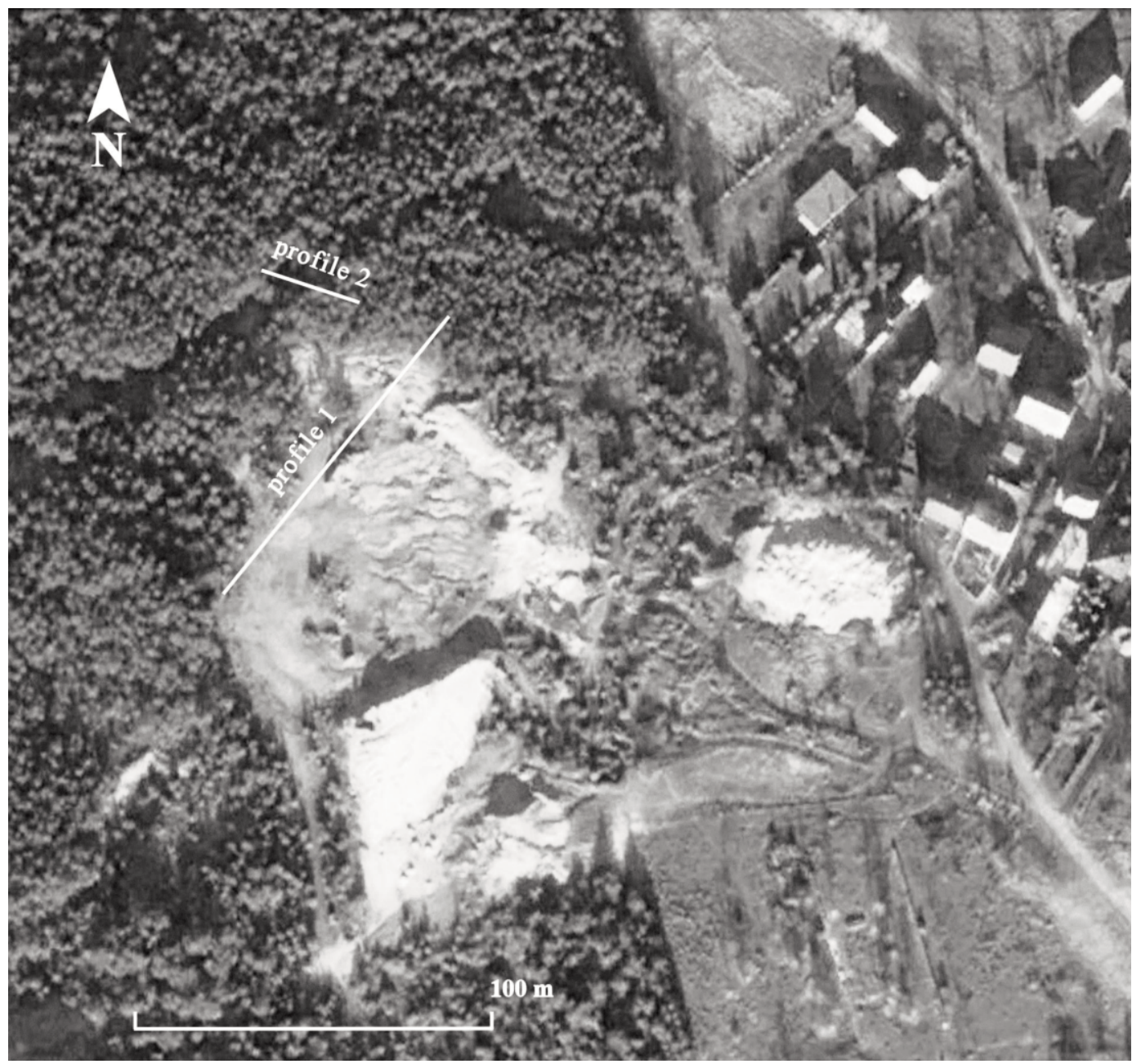

Fig. 3. The former washing plant Józef and location of geoelectrical profiles. 
was situated between piles, crossed both types of waste and its northeast end attained the unpolluted area. The second one (profile 2) was set in the area which according the EM survey had been identified as unpolluted. Resistivity and induced polarization data were collected using the dipoledipole configuration with electrode spacing of $2.5 \mathrm{~m}$ for profile 1 (length of survey line $100 \mathrm{~m}$ ) and $1.5 \mathrm{~m}$ for profile 2 (length of line $30 \mathrm{~m}$ ). The initial applied current intensity was defined at $200 \mathrm{~mA}$, and a minimum output intensity was set at $50 \mathrm{~mA}$ to obtain the best feasible data quality, which is important in the IP study. The assumed minimum current was not possible to be transmitted in the northern part of the profile. On that account for profile 2 the minimum intensity was reduced to $20 \mathrm{~mA}$. The results of the resistivity and induced polarization inversion obtained with the use of Res2DInv software are illustrated in Figs. 4 and 5. Resistivity sections are presented in a uniform scale of colour. Induced polarization is shown in terms of normalized chargeability, which depends only on lithological factors such as mineral composition, grain fraction, porosity, and permeability [24].

Profile 2 was located in the unpolluted area according to the conductivity measurements [1]. For this profile only a shallow reconnaissance up to a depth of $3.5 \mathrm{~m}$ was conducted. The results obtained can be seen in Fig. 4. The resistivity for the whole search line is very high - considerably above $3 \mathrm{k} \Omega \mathrm{m}$, and the normalized chargeability is very low - below $2 \mu \mathrm{S} / \mathrm{m}$. These values are attributed to the Quaternary fluvioglacial sand present in the dump surroundings. The slight decrease of resistivity and increase of normalized chargeability is observed at a shallow depth only in the southern part of the section.

The deeper resistivity section obtained for profile 1 exhibits a three-layer structure (Fig. 5). This search line was situated at the foot of the waste dump, at the same level (347 $\mathrm{m}$ a.s.1.) as the archival boreholes in the geological cross-section. According to Fig. 2 the roof of the diplopora dolomite was expected to be at a depth of 6-8 m. Below this depth the resistivity and the normalized chargeability values obtained are not typical for those for carbonate rocks. The resistivity is low and the normalized chargeability is higher than those given in literature [32]. The diplopora dolomite does not contain ore minerals and thus the observed values may indicate a marly character of dolomites. Another possible reason for such a situation is the existence of pores and fissures in dolomites filled with the clayey particles, which were washed out of the overlaying weathered sediments.

In the cross-section, layer lying directly above the dolomite is a layer several meters thick that is characterized by resistivity in a range of $6-20 \Omega \mathrm{m}$. The low resistivity only partially correlated with the increased normalized chargeability indicates that zones built of the clay or the clayey diluvium of the Triassic rocks in the surveyed area are noncontiguous and exist only in a fragmentary form as isolated pieces. In the studied area these sediments cannot shield the dumping site.

The top layer is built of the waste material deposited probably on the fluvioglacial sands. It can be observed that its thickness slightly increases from SW to NE, but does not exceed 2.5-4 $\mathrm{m}$. This layer is characterized by different electrical properties than the clean sands. The resistivity values exceed $200 \Omega \mathrm{m}$ and increase to the northeast up to $2 \mathrm{k} \Omega \mathrm{m}$. The normalized chargeability is low in comparison to that ascertained for the deeper clayey sediments.

At a distance of $68-72 \mathrm{~m}$ of the profile the resistivity decreases significantly to the level of $20-30 \Omega \mathrm{m}$ at a depth of 1-2 $\mathrm{m}$, and the resistivity decrease correlates with the
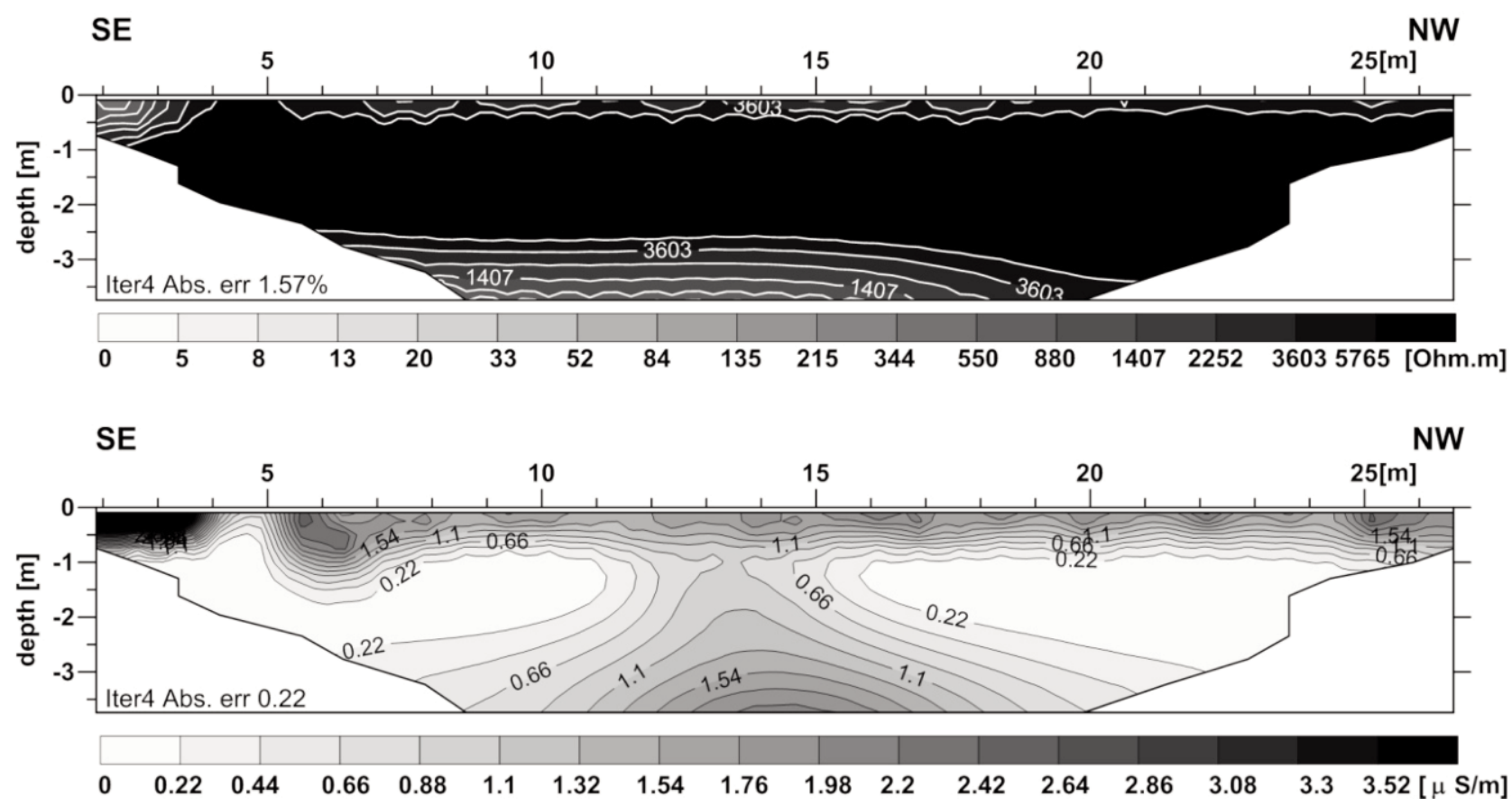

Fig. 4. The former washing plant Józef and inverted resistivity (upper) and inverted normalized chargeability (lower) sections obtained for profile 2 . 
increased normalized chargeability. In this interval the grey waste is visible on the surface. The anomaly obtained possibly indicates a part of the grey waste rich in the unweathered $\mathrm{Pb}$ and $\mathrm{Fe}$ sulphides. After a long-lasting storage period, oxidation of the sulphide minerals in the top layer of rusty and grey waste is almost certain. Non-oxidized sulphides, especially galena and marcasite (sphalerite does not exhibit the induced polarization effect [32]), can exist only near the bottom of the waste layer. Within the rusty waste the initial content of the sulphides was considerably lower due to the ore initial composition, and the oxidation process was more intensive because of its significant permeability. In a consequence of long-lasting chemical transformations the $\mathrm{Zn}, \mathrm{Pb}$, and Fe ions were bound in non-polarizable carbonates that can be observed in the waste [1] and thus their vertical migration was limited. It can be found in literature [33] that the sands that exist below the rusty waste show considerably lower contents of metals and meet requirements established for industrial soils.

\section{Ujków - Sinkhole No. 71}

Several years ago some attempts to reclaim the former excavations with the use of tailings were made. The two cavities, situated near each other, were filled with the waste that came from the nearby tailing pond. One of them was a sand pit. The second one, smaller, was formed as a result of the underground exploitation of the $\mathrm{Zn}-\mathrm{Pb}$ ores. In both cases, soon after the end of the reclamation process numerous fissures, parallel to the edges of the excavations, appeared near the borders. It is a reasonable assumption that they were formed as a result of leaching of the deposited material into surrounding rocks. The geoelectrical measurements were carried out only on the smaller of these areas. The larger one was inaccessible because of the dense plant cover. Geoelectrical measurements were taken in order to identify the structure of material used to fill the sinkhole. The second aim was to recognize the reason for the fissures formation. Finally, potential zones of the rainwater infiltration had to be indicated.

The sinkhole that was the subject of investigation was formed as an effect of underground exploitation. The $\mathrm{Zn}-\mathrm{Pb}$ ores were found in dolomites belonging to the highest part of the Lower Triassic [34]. The exploited deposit was lensshaped with a thickness of over $30 \mathrm{~m}$. It was surrounded by the strongly cracked karstic dolomites and limestone. Mining works in the investigated site were conducted in the 1960s and 1970s. The excavation method strongly influenced the size and shape of the sinkhole. Its area was 3.8 ha and maximum depth reached $38 \mathrm{~m}$. The base of the sinkhole had a shape of an irregular polygon elongated toward NNW-SSE. The walls were very steep; the dip approximated 70-80 degrees. From the south the approach flap was situated.

Due to intensive mining works that resulted in deep drainage of the Triassic aquifer, the bottom of the sinkhole
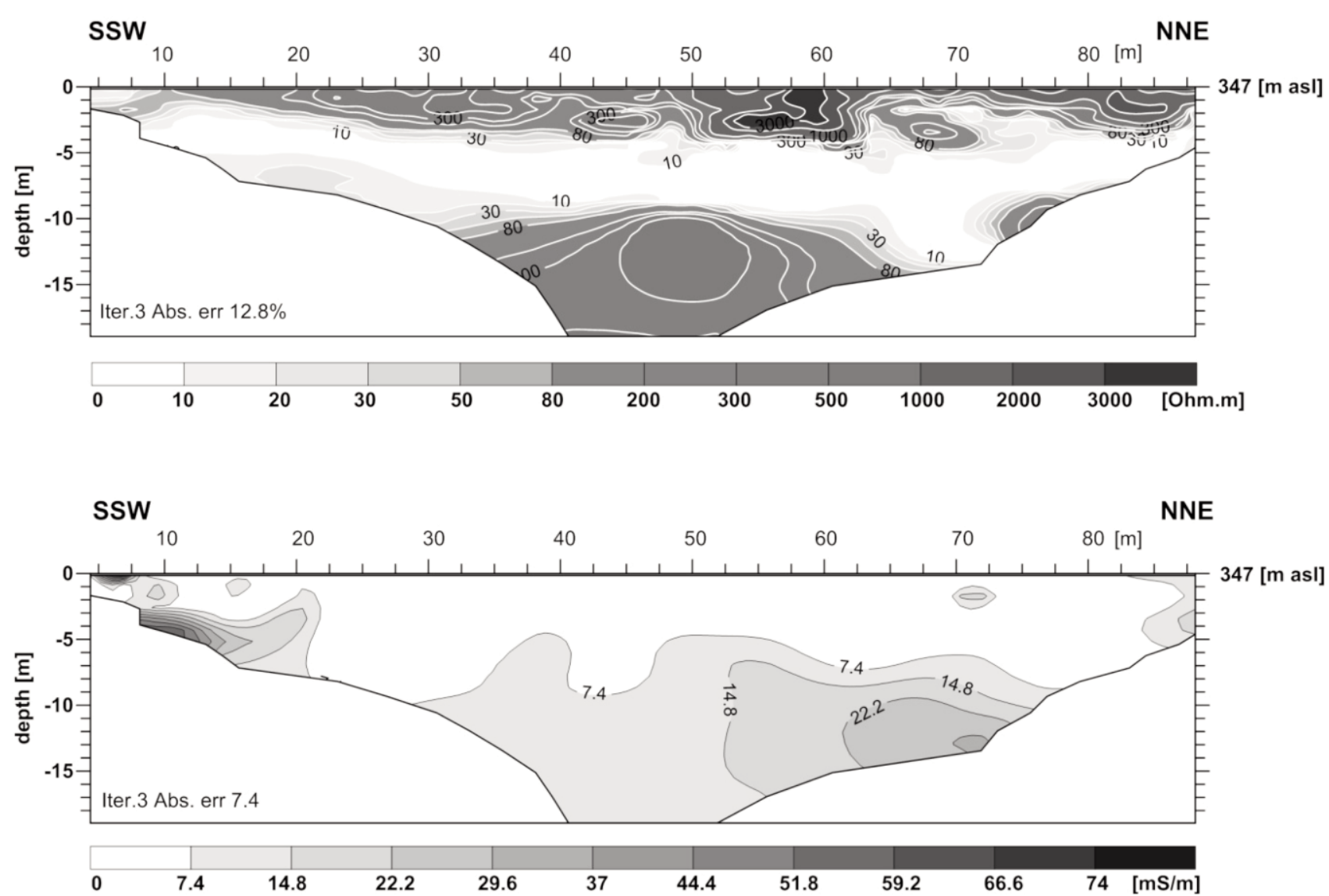

Fig. 5. The former washing plant Józef and inverted resistivity (upper) and inverted normalized chargeability (lower) sections obtained for profile 1 . 
Table 1. The content of select metal elements in waste stored in the Józef waste dump in reference to the Polish standards [1, 31].

\begin{tabular}{|c|c|c|c|}
\hline & $\begin{array}{c}\text { Standards for } \\
\text { industrial soils } \\
{[\mathrm{mg} / \mathrm{kg}]}\end{array}$ & $\begin{array}{c}\text { Rusty waste } \\
{[\mathrm{mg} / \mathrm{kg}]}\end{array}$ & $\begin{array}{c}\text { Grey waste } \\
{[\mathrm{mg} / \mathrm{kg}]}\end{array}$ \\
\hline $\mathrm{Zn}$ & 1 & $33,835-121,501$ & $10,315-27,814$ \\
\hline $\mathrm{Pb}$ & 600 & $8550-19,381$ & $20,352-208,869$ \\
\hline $\mathrm{Fe}$ & not defined & $47,571-114,194$ & $23,363-146,909$ \\
\hline $\mathrm{Mn}$ & not defined & $183-781$ & $8-968$ \\
\hline $\mathrm{Cd}$ & 15 & $152-477$ & $44-180$ \\
\hline $\mathrm{Tl}$ & not defined & $5-79$ & $1-513$ \\
\hline
\end{tabular}

is situated considerably above the water level (c.a. $45 \mathrm{~m}$ ). The underground water flow direction in the area of sinkhole No. 71 is north.

During 1995-2004 the sinkhole was reclaimed. At first, the sealing layer was constructed on the floor and sidewalls. This layer was built of clay with the filtration coefficient below $10-8 \mathrm{~m} / \mathrm{s}$. The sinkhole was filled with waste mater-
Table 2. The chemical composition of tailings and slag deposited in sinkhole No. 71 [34-36].

\begin{tabular}{|c|c|c|c|}
\hline \multicolumn{2}{|c|}{ Tailing } & \multicolumn{2}{|c|}{ Slag } \\
\hline $\begin{array}{l}\text { Compound/ } \\
\text { element }\end{array}$ & Content [\%] & $\begin{array}{c}\text { Compound/ } \\
\text { element }\end{array}$ & Content $[\%]$ \\
\hline $\mathrm{SiO}_{2}$ & $5.5-7$ & $\mathrm{SiO}_{2}$ & $<33$ \\
\hline $\mathrm{CaO}$ & $23.5-26.5$ & $\mathrm{CaO}$ & $<42$ \\
\hline $\mathrm{MgO}$ & $11.9-13.9$ & $\mathrm{MgO}$ & $<20$ \\
\hline $\mathrm{Fe}_{2} \mathrm{O}_{3}$ & $9.1-11.8$ & $\mathrm{Fe}_{2} \mathrm{O}_{3}$ & $<10$ \\
\hline $\mathrm{S}_{\text {tot. }}$ & $7.42-8.82$ & $\mathrm{~S}_{\text {tot. }}$ & $<5$ \\
\hline $\mathrm{Fe}_{\text {tot. }}$ & $7.74-8.52$ & $\mathrm{Fe}_{\text {tot. }}$ & $<15$ \\
\hline $\mathrm{FeS}_{2}$ & 8.8-13.9 & & \\
\hline $\mathrm{ZnO}$ & $0.38-0.57$ & & \\
\hline $\mathrm{PbO}$ & $0.25-0.36$ & & \\
\hline $\mathrm{Pb}$ & $0.36-0.5$ & & \\
\hline $\mathrm{Zn}$ & $0.92-1.32$ & & \\
\hline $\mathrm{Cd}$ & $0.007-0.015$ & & \\
\hline $\mathrm{Mn}$ & $0.08-0.1$ & & \\
\hline
\end{tabular}

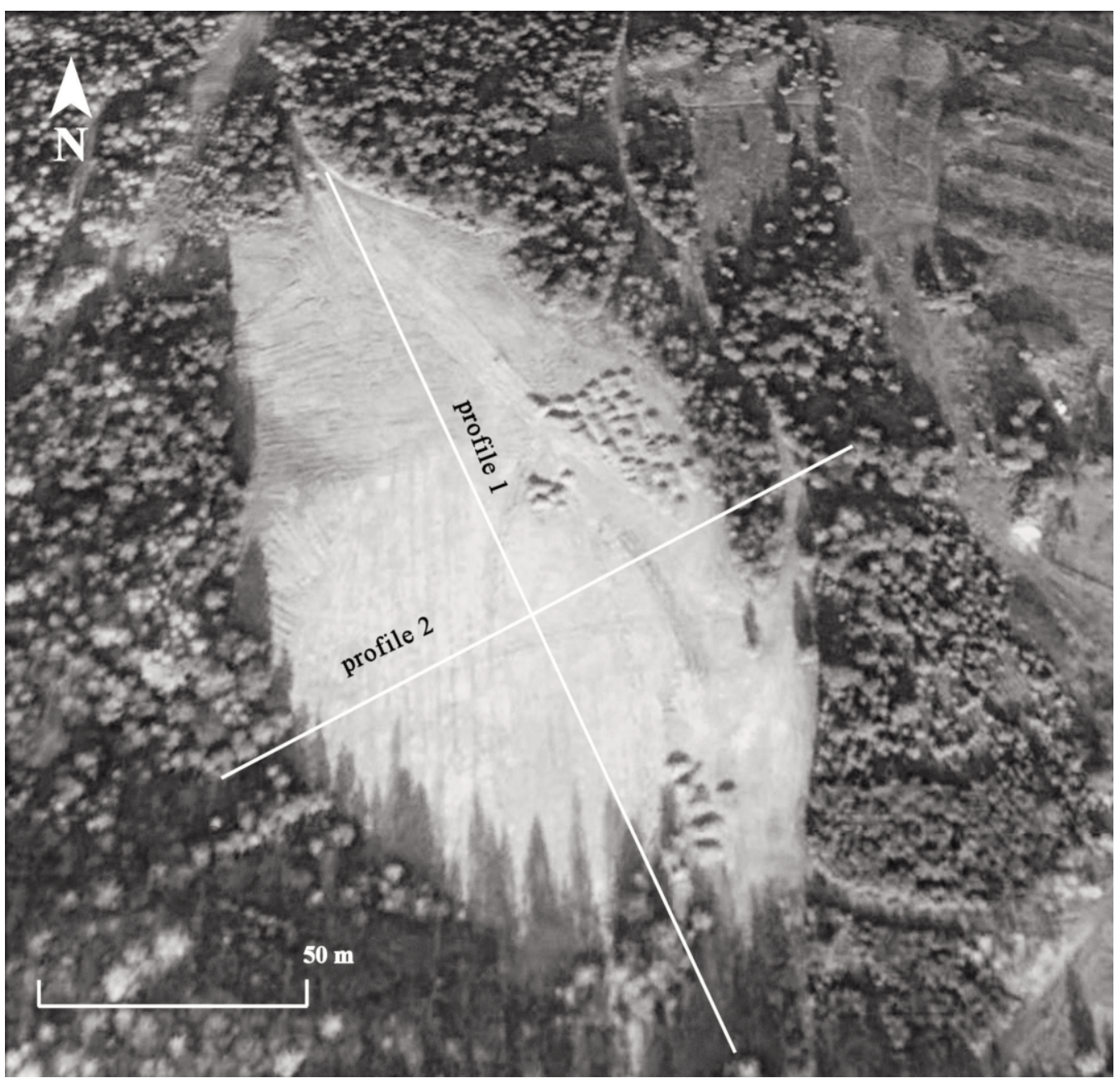

Fig. 6. Sinkhole No. 71 and the location of the geoelectrical search lines. 
ial in two steps [34]. About 70\% of the sinkhole volume was filled with tailings from the tailing lagoon. This waste consisted of sandy and dusty fraction, thus it can be qualified as a clayey sand. Tailings consisted of dolomite $\mathrm{CaMg}\left(\mathrm{CO}_{3}\right)_{2}$ (77\%), marcasite $\mathrm{FeS}_{2}$ (max. 17\%), smithsonite $\mathrm{Zn}\left(\mathrm{CO}_{3}\right)$ (1\%), cerussite $\mathrm{PbCO}_{3}(0.5 \%)$, and galena $\mathrm{PbS}(0.12 \%)$. The clay minerals (illite, kaolinite) are also noticeable [11]. Only old tailings, repeatedly washed by infiltrating rainwater, were used as filler material. Its $\mathrm{pH}$ value showed a neutral or slightly acidic reaction. That was the crucial argument for the above-referenced use of tailing [34].

The remaining part of the sinkhole was filled with a slag delivered from the nearby smelting works. This material contained a considerable quantity of soluble sulphur compounds and heavy metals (Table 2). The $0.6 \mathrm{~m}$ thick layer of clays with a low filtration coefficient and $0.5 \mathrm{~m}$ soil layer were placed on top of the waste.

Two measurement lines were situated in the reclaimed area (Fig. 6). The first, with a length of $190 \mathrm{~m}$ and NNWSSE direction, was traced parallel to the longer axis of the former sinkhole. The second perpendicular line was $140 \mathrm{~m}$ long. The smallest distance between the electrodes was established at $5 \mathrm{~m}$. A minimal current intensity was $50 \mathrm{~mA}$. In contrast to the Józef waste dump, at this site the field conditions were rather favorable for geoelectrical study as the upper soil layer was moist, which influenced the grounding of the electrodes and the electrical contact.

The depth of investigation for profiles 1 and 2 was about $25 \mathrm{~m}$. At first, variations of electrical resistivity for both profiles were studied. Results obtained are presented in Fig. 7. For optimal visualisation, both maps of resistivity are plotted in the same standardized scale of colour.
The shape of the former sinkhole can be easily observed in both cross-sections. The existence of Triassic carbonate rocks can be seen as a moderate and highly resistive zone in the marginal and bottom parts of the sections. A steep slope of the sinkhole walls can be observed. The floor of the sinkhole cannot be recognized unambiguously due to its depth, which exceeds the range of the measurement, especially in the northern part. For profile 2 the sealing layer seems to be effective. The obtained results show no signs of the deposited material leaching out of the storage yard.

For both sections it can be observed that the filling material is characterized by a noticeable dual structure. Material stored at the bottom of the sinkhole exhibits very low resistivity ranging from about $1 \Omega \mathrm{m}$ to $30 \Omega \mathrm{m}$. For the upper part moderate resistivity values (30-130 $\Omega \mathrm{m})$ are a distinctive feature, but the smaller areas characterized by very low resistivity can also be noticed. The tailings used for filling the hole before its utilization for many years had been stored. A time between the end of the reclamation process and the geoelectrical measurements was too short to enable the vertical differentiation of the waste (connected with the oxidizing of sulphides), thus the observed spatial changes seem to be an effect of the various electrical properties of the two kinds of the waste deposited - tailing near the bottom and slag in the top of the sink-hole.

The very low resistivities $(<4 \Omega \mathrm{m})$ that are clearly observed in both sections are disconcerting, because they may indicate the presence of contaminated water within the waste or they can result from the mineral composition of the filling material.

The induced polarization measurements that were conducted only for profile 2 , where the strong low-resistive
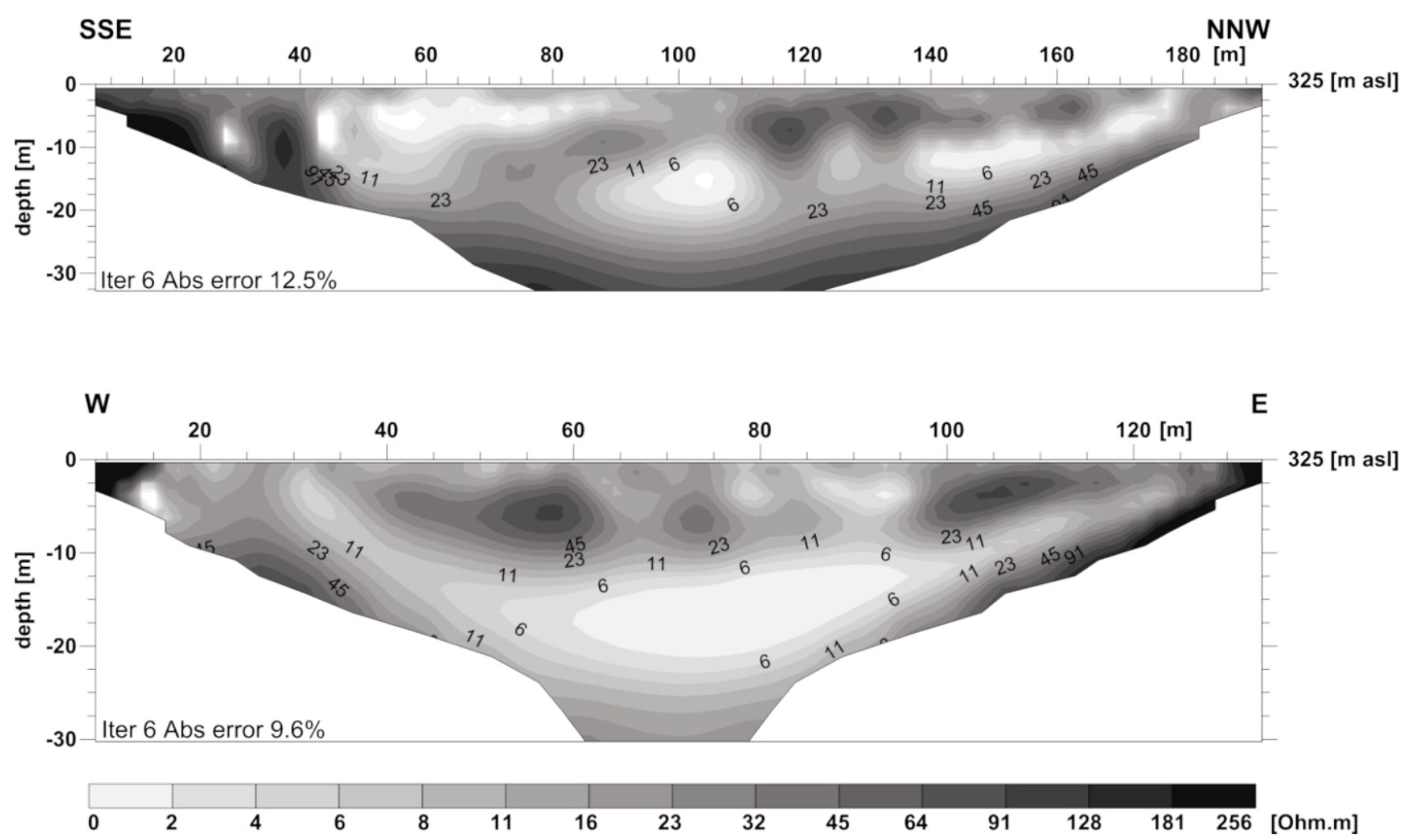

Fig. 7. Sinkhole No. 71 and resistivity sections obtained for profile 1 (upper) and for profile 2 (lower). 

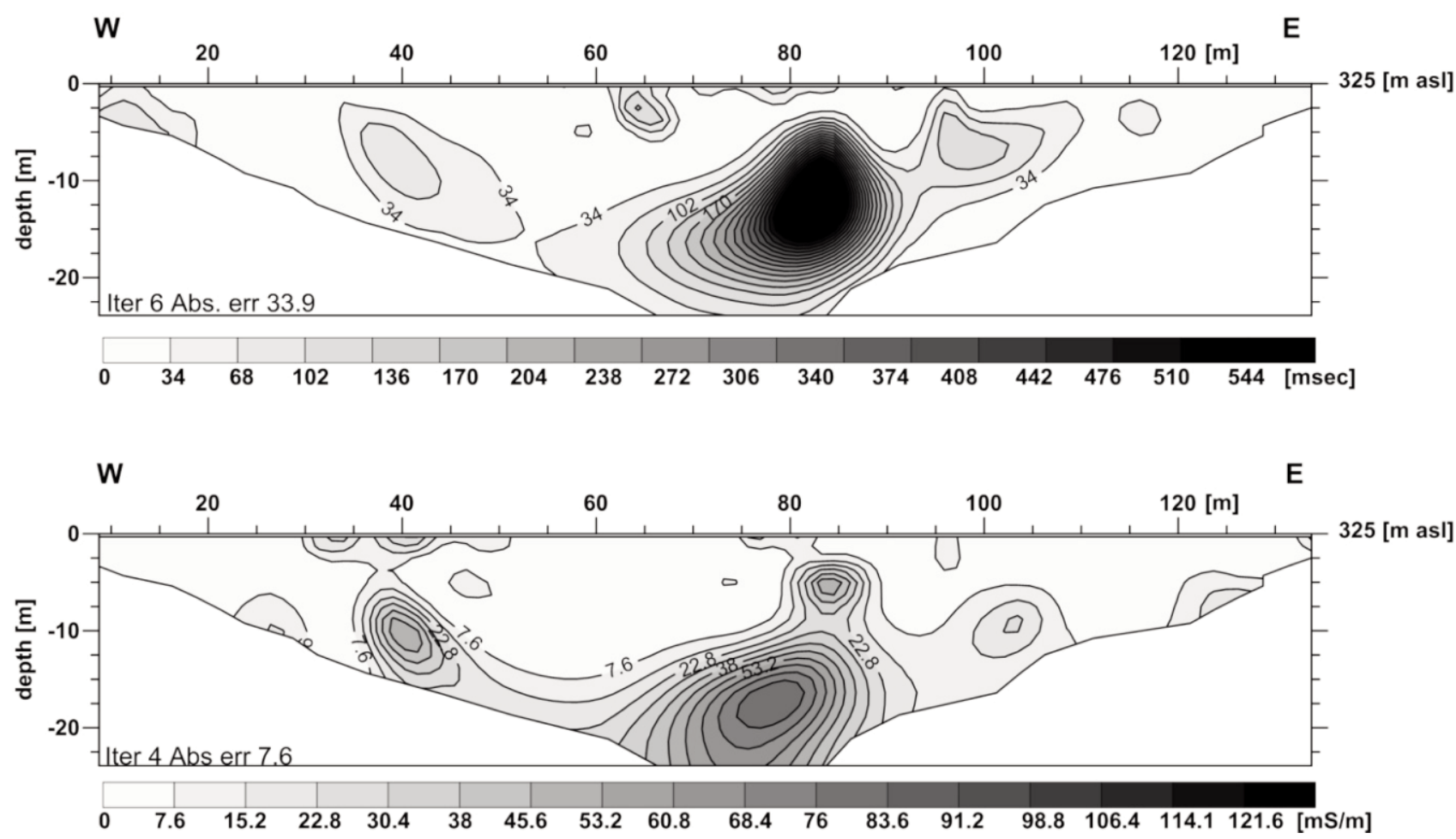

Fig. 8. Sinkhole No. 71 and inverted chargeability (upper) and normalized chargeability (lower) sections obtained for profile 2.

anomaly is observed near the bottom of the sinkhole, completed the ERT results and allowed us to identify the reason of the recognized anomaly. The obtained sections of the inverted chargeability and normalized chargeability are presented in Fig. 8. After the analyses of these sections it can be easily observed that for the above-mentioned doubtful area the decreased resistivity corresponds with increased chargeability values. Thus, it indicates that the widespread, low-resistive zone in the bottom of the sinkhole is caused by the chemical composition of the stored tailings. High values of the normalized chargeability are caused by the marcasite presence (approx. 17\%) and the content of dispersed clay minerals (up to 10\%) in the waste [36].

In profile 2 , starting from $120 \mathrm{~m}$, near the surface the raised chargeability values do not correlate with the increase of the normalized chargeability. This feature can be considered as a zone of rainfall infiltration, but resolving this problem would require more detailed measurements across the edges of the sinkhole.

The measurements performed made it possible to separate zones connected with the rock basement and both types of waste material used for reclamation of the sinkhole. It was shown that nowadays the clayey isolating layer of the side-slopes and bottom eliminates the leakage of contaminated water from the sinkhole area into the bedrock. The numerous fissures observed near the edges of the reclaimed depressions are probably caused by the gravitational densification of deposited waste. A confirmation of the results obtained by the geoelectrical reconnaissance would require direct measurements in this area, but drillings or sampling for the geochemical studies were not allowed.

\section{Conclusions}

For both of the analyzed sites noticeable differences between the waste and the natural sediments were observed. The measurements confirmed that the $\mathrm{Zn}-\mathrm{Pb}$ waste is conductive relatively to the rock material forming the surroundings of the stockyards. Moreover, recent and old tailings showed the increased normalized chargeability values. This features can be explained by the presence of metalliferous $(\mathrm{Fe}, \mathrm{Pb})$ sulphides and clay minerals. More difficult for geoelectrical identification is the historical washed waste, whose grains of $\mathrm{Pb}$ sulphide are coated by the non-polarizing carbonates, and $\mathrm{Fe}$ is bound in oxides and hydroxides in consequence of the long-lasting chemical interactions.

The combination of resistivity and induced polarization imaging appeared to be a useful instrument for detailed identification of the areas where the wastes from the $\mathrm{Zn}-\mathrm{Pb}$ ore processing were stored. The resistivity-IP measurement should be preceded by the use of faster electromagnetic or magnetic methods. In the Olkusz region the magnetic method would be effective for the initial detection of the areas where the wastes were stored, due to the concentration of goethite in washed waste, and pyrite and marcasite in tailings.

The most serious environmental threat for the areas of the post-mining waste storage in the Olkusz region seems to be the cessation of mining activity. This will cause a considerable rising of the underground water level. In consequence, processes connected with the outwashing of either a natural or artificial sealing layer will be initialized, which will result in leaching of the chemical compounds from the storage yards to the karstic aquifer. 


\section{References}

1. CABAŁA J., ŻOGAŁA B., DUBIEL R. Geochemical and geophysical study of historical $\mathrm{Zn}-\mathrm{Pb}$ ore processing waste dump areas (Southern Poland). Pol. J. Environ. Stud. 17, (5), 693, 2008.

2. Mc LERMORE V.T., DUNBAR N., TACHIE-MENSON S., DONAHUE K. The effect of weathering on the acid-producting potential of the Goathill North Rock Pile, Questa mine, NM. Tailings and Mine Waste 2010, Taylor and Francis Group, London, pp. 213-225, 2011.

3. GORE D. A., OLYPHANT G. A. Mapping the variability of groundwater quality in an abandoned tailings deposit using electromagnetic geophysical techniques. National Meeting of the American Society of Mining and Reclamation, Pittsburgh, PA Bridging Reclamation, Science and the Community. R.I. Barnhisel (Ed.), 2010.

4. VRHOVNIK P., ŠMUC N. R., DOLENEC T., SERAFIMOVSKI T., DOLENEC M. Impact of $\mathrm{Pb}-\mathrm{Zn}$ mining activity on surficial sediments of Lake Kalimanci (FYR Macedonia). Turkish J. Earth Sci., 22, 996, 2013.

5. CAPPUYNS V., ALIAN V., VASSILIEVA E., SWENNEN $\mathrm{R}$. $\mathrm{pH}$ dependent leaching behavior of $\mathrm{Zn}, \mathrm{Cd}, \mathrm{Pb}, \mathrm{Cu}$ and As from mining wastes and slags: kinetics and mineralogical control. Waste Biomass Valor, 5, 355, 2014.

6. DOLD B., WADE C., FONTBOTÉ L. Water management for acid mine drainage control at the polymetallic $\mathrm{Zn}-\mathrm{Pb}$ (Ag-Bi-Cu) deposit Cerro de Pasco, Peru. J. Geochem. Explor., 100, (2-3), 133, 2009.

7. RODRÍGUEZ L., RUIZ E., ALONSO-AZCÁRATE J., RINCÓN J. Heavy metal distribution and chemical speciation in tailings and soils around a $\mathrm{Pb}-\mathrm{Zn}$ mine in Spain. J. Environ. Manage., 90, (2), 1106, 2009,

8. BOUSSEN S., SEBEI A., SOUBRAND-COLIN M., BRIL H.F., CHAABANI A.S. ABDELJAOUAD S. Mobilization of lead-zinc rich particles from mine tailings in northern Tunisia by aeolian and run-off processes. Bull. Soc. Géol. Fr., 181, (5), 459, 2010.

9. BABBOU-ABDELMALEK CH., SEBEI A., CHAABANI F. Incurred environmental risks and potential contamination sources in an abandoned mine site. African Journal of Environmental Science and Technology, 5, (11), 894, 2011.

10. ADAMCZYK A., HAŁADUS A. The hydrogeological opinion on the influence of the washed waste ("Jozef" washing plant) on the quality of underground water. Kraków, AGH, 1996, [unpublished, In Polish].

11. BAUEREK A., CABAŁA J., ŚMIEJA-KRÓL B. Mineralogical alterations of $\mathrm{Zn}-\mathrm{Pb}$ flotation wastes of Mississippi Valley-Type Ores (Southern Poland) and their impact on contamination of rainwater runoff. Pol. J. Environ. Stud. 18, (5), 781, 2009.

12. BAUEREK A., ŁĄCZNY J. M. Contaminated water runoff from dam slopes of tailings pond of flotation plant of $\mathrm{Zn}-\mathrm{Pb}$ Mississippi Valley-type ores at Boleslaw near Olkusz. Przegląd Geologiczny, 58, (1), 54, 2010 [In Polish].

13. MOTYKA J., ADAMCZYK Z., CZOP M., D'OBRYN K. Groundwater quality impact by municipal sanitary landfill in Ujków near Olkusz (S Poland). Gospodarka surowcami mineralnymi, 21, (1), 131, 2005 [In Polish].

14. STRZYSZCZ Z. Physical, physicochemical and chemical qualities of $\mathrm{Zn}-\mathrm{Pb}$ post-flotation waste in the aspect of their biological reclamation. Arch. Ochr. Srod., 3-4, 19, 1980 [In Polish].
15. MARTÍNEZ-PAGÁN P., FAZ CANO A., ARACIL E., AROCENA J.M. Electrical Resistivity Imaging Revealed the Spatial Properties of Mine Tailing Ponds in the Sierra Minera of Southeast Spain. Journal of Environmental and Engineering Geophysics, 14, (2), 63, 2009.

16. GÓMEZ-ORTIZ D., MARTÍN-VELÁZQUEZ S., MARTÍN-CRESPO T., DE IGNACIO-SAN JOSÉ C., LILLO J. Application of electrical resistivity tomography to the environmental characterization of abandoned massive sulphide mine ponds (Iberian Pyrite Belt, SW Spain). Near Surface Geophysics, 8, 65, 2010.

17. IACOB C. Geoelectric Signatures of Tailing Ponds. In: $73^{\text {rd }}$ EAGE Conference and Exhibition incorporating SPE EUROPEC, Vienna, Austria, P187, 2011.

18. IACOB C. Geoelectrical Investigations for Tailing Ponds' Geochemical Zonation at Paraul Cailor, Romania. $74^{\text {th }}$ EAGE Conference and Exhibition incorporating SPE EUROPEC 2012, Copenhagen, Denmark, 2012.

19. IACOB C., ORZA R. Integrated interpretation of geophysical data on metalliferous mining waste deposits. In: Proc. Near Surface, $14^{\text {th }}$ European Meeting of Environmental and Engineering Geophysics, Kraków 2008, B02, 2008.

20. KURAS O., BANKS V., PALUMBO-ROE B., KLINCK B. Geophysical imaging of a tailings lagoon at an abandoned lead-zinc mine in the Central Wales Orefield, UK. In: Proc. Near Surface, $14^{\text {th }}$ European Meeting of Environmental and Engineering Geophysics, Kraków 2008, B03, 2008.

21. LGHOUL M., TEIXIDÓ T., PEŇA J.A., KCHIKACH A., GUÉRIN R., HAKKOU R. Electrical and seismic tomography used to image the structure of a tailings pond at the abandoned Kettara Mine, Morocco. Near Surface Geoscience $2012-18^{\text {th }}$ European Meeting of Environmental and Engineering Geophysics, Paris, P79, 2012.

22. HUOTARI-HALKOSAARI T.K.T., LERSSI J.M. Electrical resistivity tomography and transient electromagnetic survey in Luikonlahti tailings impoundment area, Near Surface Geoscience $2012-18^{\text {th }}$ European Meeting of Environmental and Engineering Geophysics, Paris B24, 2012.

23. SHERRIFF B. L., FERGUSON I. J., GUPTON M. W., VANGULCK J. F., SIDENKO N., PRISCU C., PÉREZFLORES M., GÓMEZ-TREVIÑO E. A geophysical and geotechnical study to determine the hydrological regime of the Central Manitoba gold mine tailings deposit. Can. Geotech. J., 46, (1), 69, 2009.

24. SLATER L., LESMES D. IP interpretation in environmental investigations. Geophysics, 67, 68, 2002.

25. KEMNA A., BINLEY A., SLATER L. Crosshole IP imaging for engineering and environmental applications. Geophysics, 69, 97, 2004.

26. BÖRNER F., SCHOPPER J., WELLER A. Evaluation of transport and storage properties in the soil and groundwater zone from induced polarization measurements. Geophys. Prospect., 44, 583, 1996.

27. YUVAL, OLDENBURG D.W. DC resistivity and IP methods in acid mine drainage problems: results from the Copper Cliff mine tailings impoundments. J. Appl. Geophys., 34, 187, 1996.

28. CAMPBELL D.L., FITTERMAN D.V. Geoelectrical methods for investigating mine dumps. In: Proceedings of the Fifth International Conference on Acid Rock Drainage, Denver, Colorado, 2000.

29. DE VILLIERS D.P., WEBB S., WEIERSBYE I., JONES M. Induced polarisation effect associated with acidic groundwater in Witwatersrand Gold Mining Areas. 13 ${ }^{\text {th }}$ SAGA Biennial Conference and Exhibition, 2013. 
30. PLACENCIA-GÓMEZ E., PARVIAINEN A., SLATER L., LEVEINEN J. Spectral induced polarization (SIP) response of mine tailings. Journal of Contaminant Hydrology, 173, 8, 2015.

31. Ordinance of the Minister of the Environment of $9^{\text {th }}$ September 2002 on soil and ground quality standards. Journal of Laws, Poland 165, Item 1359, 2002.

32. TELFORD W.M., GELDART L.P., SHERIFF R.E. Applied Geophysics. Cambridge University Press, New York, 1990.

33. CABAŁA J. Heavy metals in ground soil environment of the Olkusz area of $\mathrm{Zn}-\mathrm{Pb}$ ore exploitation. Wydawnictwo Uniwersytetu Śląskiego, Katowice, 2009 [In Polish].
34. HORDECKI A. The environmental impact assessment of the reclamation of the "Krazek" excavation and sink-hole number 71. Katowice, 1995 [unpublished, In Polish].

35. GIRCZYS J., SOBIK-SZOŁTYSEK J. Non- ferrous industry waste. Monografie 8, Wyd. Polit. Częstochowskiej, 2002 [In Polish].

36. PAJOR G. The post-flotation waste disposal in the ZGH "Boleslaw" S.A. in Bukowno. - Zrównoważone zarządzanie obszarami poprzemysłowymi, ed. Kudełko J., Kulczycka J., Wirth H., Publ. IGSMiE PAN, Kraków, pp. 819, 2005 [In Polish]. 
